\title{
Marjolin's Ulcer with Axillary Lymph Node Metastasis
}

\section{Úlcera de Marjolin com Metastização Ganglionar Axilar}

Manuela Graça FERNANDES ${ }^{1}$, Mariana BRANDÃO², Eduardo Mijare DIAS ${ }^{3}$

Acta Med Port 2018 Sep;31(9):515-515 - https://doi.org/10.20344/amp.10673

Keywords: Carcinoma, Squamous Cell; Lymph Nodes; Lymphatic Metastasis; Skin Ulcer

Palavras-chave: Carcinoma de Células Escamosas; Gânglios Linfáticos; Metástase Linfática; Úlcera Cutânea

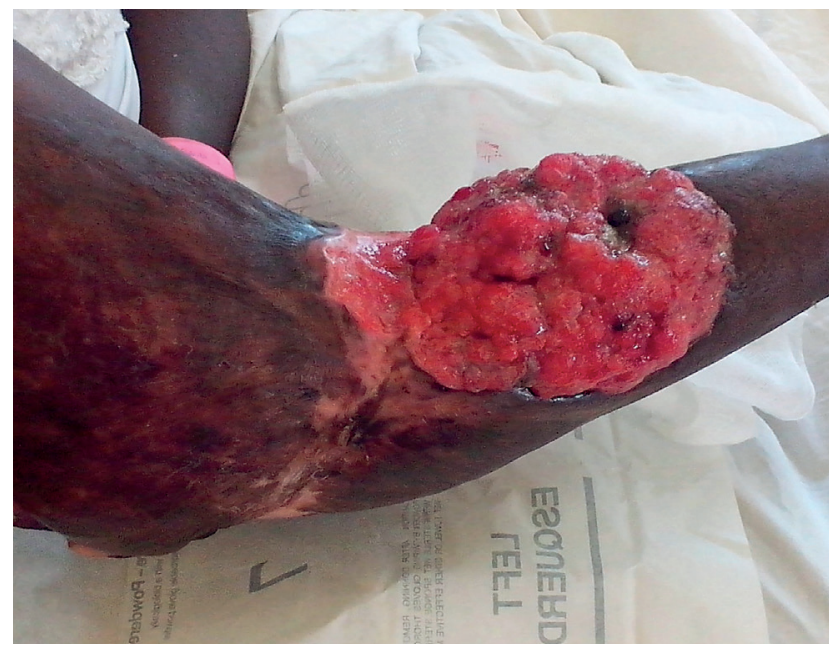

Figure 1 - Ulcerated exophytic tumor on the right forearm arising from burn scar, compatible with Marjolin's ulcer

A 25-year-old female, who had a burn injury of the right upper limb during childhood, presented with a 4 months history of an ulcerated exophytic tumor on the burn scar (Fig. 1). There was also a 2 months history of right axillary adenopathy (Fig. 2). A biopsy of the ulcer showed a squamous cell carcinoma (SCC). Staging exams revealed bone invasion, ipsilateral axillary lymph node metastasis and no distant metastasis. This patient was treated with a radical excision of the lesion by trans-humeral amputation

\section{PROTECTION OF HUMANS AND ANIMALS}

The authors declare that the procedures were followed according to the regulations established by the Clinical Research and Ethics Committee and to the Helsinki Declaration of the World Medical Association.

\section{DATA CONFIDENTIALITY}

The authors declare having followed the protocols in use at their working center regarding patients' data publication.

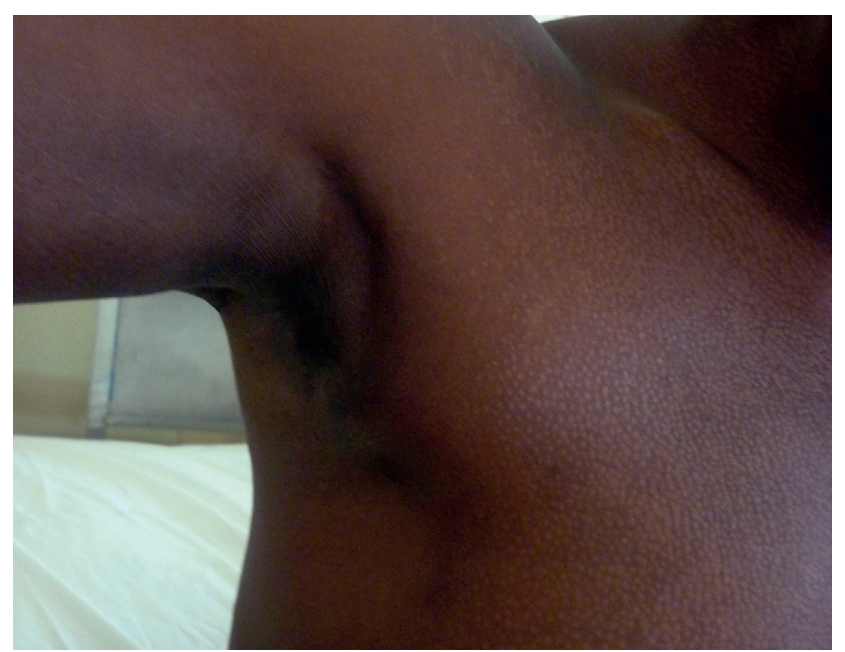

Figure 2 - Right axillary adenopathy

and a right axillary lymphadenectomy.

The lesion was a Marjolin's ulcer, characterized by a skin cancer that develops from scar tissue or chronic ulcers. ${ }^{1-3}$ The SCC is the most frequent pathological type, but in Marjolin's ulcer it is more aggressive than in the primary cutaneous SCC, with a higher potential for early metastasis. This determines the need for early diagnosis and prompt surgical intervention. ${ }^{1-3}$

\section{PATIENT CONSENT}

Obtained.

\section{CONFLICTS OF INTEREST}

All authors report no conflict of interest.

\section{FUNDING SOURCES}

This research received no specific grant from any funding agency in the public, commercial, or not-for-profit sectors.

\section{REFERENCES}

1. Bazaliński D, Przybek-Mita J, Barańska B, Więch P. Marjolin's ulcer in chronic wounds - review of available literature. Contemp Oncol. 2017;21:197-202.

2. Iqbal FM, Sinha Y, Jaffe W. Marjolin's ulcer: a rare entity with a call for early diagnosis. BMJ Case Rep. 2015: 15;2015.

3. Shen R, Zhang J, Zhang F, DU Y, Liang W, Xu L, et al. Clinical characteristics and therapeutic analysis of 51 patients with Marjolin's ulcers. Exp Ther Med. 2015;10:1364-74.

1. Surgery Department. Centro Hospitalar Tondela Viseu. Tondela. Portugal.

2. Academic Promoting Team. Institut Jules Bordet. Bruxelles. Belgium.

3. Surgery Department. Hospital Central de Maputo. Maputo. Mozambique.

$凶$ Autor correspondente: Manuela Graça Fernandes. manuelamgf@gmail.com

Recebido: 17 de abril de 2018 - Aceite: 15 de maio de 2018 | Copyright @ Ordem dos Médicos 2018 